\title{
Pelatihan Peningkatan Kapasitas Manajemen Olahraga Pengurus KONI NTT
}

\author{
Soemardiawan, Susi Yundarwati, Intan Primayanti, Sukarman \\ Fakultas Ilmu Keolahragaan dan Kesehatan Masyarakat, FIKKM UNDIKMA \\ umanksoemardiawan84@gmail.com
}

\begin{abstract}
Abstrak; Pengabdian ini bertujuan untuk mengetahui peningkatan kapasitaskemampuan manajemen olahraga pengurus Koni NTT Tahun 2019. Metode penelitian ini adalah metode deskriptif.Jumlah sampel sebanyak 34 orang dengan tehnik pengambilan sampel dengan tehnik purposive sampling. Instrumen penelitian berupa angket dengan tehnik analisis data dengan membandingkan dua rata rata pree test sebesar $=78$ (sedang), dan rata rata post test sebesar $=84,5$ (baik). Hasil penelitian ini menunjukan terdapat peningkatan yang signifikan kapasitas kemampuan manajemen pengurus provinsi cabang olahraga di Pengurus NTT Tahun 2019.Dengan demikian dapat dinyatakan bahwa melalui kegiatan seminar, pelatihan dan workshop kapasitas manajemen olahraga menjadi meningkat, point penting yang dapat diskusikan daman mencermati hasil penelitian tersebut adalah (1) skor yang memperoleh nilai yang tinggi dari 9 meteri adalah: (a) Manajemen penyelenggaraan event olahraga, (b) Manajemen pengiriman kontingen ke event olahraga, (c) Menejemen kepemimpinan dalam organisasi olahraga (d), presentasi kelompok yaitu. manajemen event dan manajemen mengiriman atlet. (2) Sedangkan yang memeperoleh skor ratarata adalah materi (a) olimpism sebagai filosofi dasar organisasi olahraga, (b) Manajemen pembinaan olahraga prestasi, (c) Manajemen) indentifikasi bakat olahragawan, (d) Menejemen keuangan dalam organisasi olahraga dan (3) Sedangkan materi (a) Pengetahuan tentang anti doping sangat rendah,Temuan yang menarik dalam penelitian ini adalah(1) bahwa pengurus propinsi cabang olahraga mempunyai latar belakang yang berbeda beda akan tetapi memiliki komitmen yang tinggi dalam memajukan prestasi olahraga di NTT, (3) karena banyak pengurus cabang olahraga yang tidak mempunyai latar belakang organisasi olahraga mereka sangat antusias dalam mengikuti seminar, pelatihan tersebut, (3) masih banyak para pengurus cabang olahraga yang merangkap jabatan dengan organisasi lainya sehingga kurang focus dalam menjalankan organisasi olahraga yang dipimpinya..(4) Pendanaan operasional pengurus cabang olahraga berasal dari patungan pengurus dan ketuanya.
\end{abstract}

\section{Kata Kunci :Pelatihan,Kapsitas, Manjemen Olahraga.}

\section{PENDAHULUAN}

Menjadi seorang pemimpin sebuah organisasi olahraga bukanlah pekerjaan yang mudah. Beberapa kemampuan harus dimiliki agar kepemimpinanya berhasil sebab keberhasilan seseorang dalam memimpin organisasi olahraga ditentukan oleh kemampuan manajerial yang dimilki antara lain; kemampuan memimpin, kemampuan membina, kemampuan menyelenggarakan, dan kemampuan menejemen keuangan. Hal ini sesuai yang dikemukakan oleh: Mochamad S (2015), Ibrahim, M. Izzat. (2015), Agus Abdillah. (2013). Selain itu seorang menejer harus mempunyai inovasi dan mempunyai komitmen kepemimpinan yang tinggi, mempunyai Karakteristik pro inovasi, memiliki kemampuan berorgansasi dan mampu menjalankan dengan cermat berorganisiasi. Larena Hoeber (2012).Untuk itu dalam penelitian ini akan diung.

Kapasitas manajemen olah raga bagi seseorang akan menunjukan tingkat keberhasilan seseorang dalam memimpin sebuah organisasi olahraga. Karena dalam organisasi olahraga menaungi banyak bidang yang merupakan bagian yang penting yang harus dikendalikan untuk dapat dijadikan alat untuk mencapai sebuah tujuan.Tujuan akhir dari manajemenolahraga adalah kesuksesan para atletnya dalam mengikuti kejuaraan baik itu secara nasional maupun internasional. Seperti dikemukakan oleh Agung Nugroho, (2010), Rizaldi (2015), Setio Nugroho(2016). Nurul Hidayah, (2016), Teori manajemen yang mendukung keberhasilan salam manajemen 
olahraga antara lain; Planing, Organizing, Coordinating, Motivating, Controlling, Directing, Staffing, Innovation, Representation, Supervising, Communicating, Actuating, Appraising, Commanding, Reporting, Executing, dan Budgeting. Utomo, Budi. (2015), Simon Darcy.(2006), Dari sekian banyak fungsi, ada yang memasukkan coordinating sebagai bagian essensial dari organizing, sedangkan communicating ada yang memasukkannya ke dalam motivating, dan reporting hanya sebagai alat kontrol semata bukan merupakan fungsi yang terpisah. Keberhasilan suatu organisasi olahraga prestasi selalu dikaitkan dengan seberapa jauh prestasi olahragawan yang dihasilkan oleh organisasi tersebut.Di Sumatera Utara tercatat memiliki 48 organisasi olahraga yang disebut dengan pengurus propinsi cabang olahraga. Koni Sumut (2017).

Kesemuan yaitu memerlukan mamajemen yang baik dari seluruh anggota yang ada untuk dapat memperoleh keberhasilan yang maksimal. Untuk meningkatkan kapasitas para menajer diperlukan suatu cara yang ilmiah seperti seminar, penataran, pelatihan, workshop, dan lain sebagainya. Sehingga diharapkan akan mampu mengendalikan institusi yang dipimpinya. Untuk meningkatkan kapasitas manajemen olahraga pengurus propinsi cabang olahraga di Sumatera Utara, dilakukan penelitian terhadap para peminpin olahraga tersebut yaitu dengan mengadakan seminar, pelatihan dan workshop selama 3 (tiga) hari dengan materi: (1) Olimpism sebagai filosofi dasar organisasi olahraga, (2) Manajemen pembinaan olahraga prestasi, (3) Manajemen penyelenggaraan event olahraga, (4) Manajemen indentifikasi bakat olahragawan, (5) Manajemen pengiriman kontingen ke event olahraga, (6) Pengetahuan tentang anti doping, (7) Menejemen kepemimpinan dalam organisasi olahraga, (8) Menejemen keuangan dalam organisasi olahraga (9), presentasi kelompok yaitu. manajemen event dan manajemen mengiriman atlet.[13] Koni Pusat (2017) yang dilakukan oleh koni sumut bekerjasama dengan Koni Pusat.

\section{METODE PELAKSANAAN PROGRAM PENGABDIAN MASYARAKAT}

Hasil akhir dari kegiatan pengabdian memberikan solusi kepada pengurus KONI NTT adal hal Hasil pengabdian ini menunjukan terdapat peningkatan yang signifikan kapasitas kemampuan manajemen pengurus provinsi Koni NTT tahun 2019. Dengan melihat hasil tersebut Metode penelitian ini adalah metode deskriptip.Jumlah sampel sebanyak 34 orang dengan teknik purposive sampling dari 34 populasi yaitu cabang olahraga yang atletnya lolos PON ke XIX di Irian Jaya tahun 2020.Waktu pelaksanaan penelitian selama 3 hari dengan desain penelitian pree-test-post test, Instrumen penelitian berupa angket dan teknik analisis data dengan membadingkan dua ratarata,[13]Hasan (2002). Dengan kriteria, 90-100 Sangat Baik (SB),8089 Baik (B), 70-79 Sedang (S), 60-69 Kurang $(\mathrm{K})<59$ Kurang Sekali (KS).

\section{Persiapaan Pelatihan}

Tahapan persiapan merupakan tahapa awal seblum melakaukan pelaksanaan program pengabdian kepada mayarakat. Dalam tahapan ini ada beberapa hal yang dilakukan yakni koordinasi internal, dilakukan oleh tim untk melaksanakan secara konseptual, operasional, serta job description masing masing anggota, penentuan dan rekrutment peserta pelatihan dalam perekrutan peserta dipersyaratkan memiliki keterampilan yang memadai dalam bidang Dalam bidang majemen olahraga.

\section{Pelaksanaan Pelatihan}

Pengabdian ini dilaksanakan di Koni NTT Jalan Bung Karno 1Mataram Mataram pada bulan Oktober tahun 2019 sampai dengan selesai.

\section{1) Peyajian Materi}

Materi yang disajikan terkait dengan pengenalan dan penggunaan program meningkatkan Hasil pengabdian ini menunjukan terdapat peningkatan yang signifikan kapasitas kemampuan manajemen pengurus provinsi Koni NTT tahun. 2019 Penyajian ini diploting dalam 1 hari tatap muka. Penyaji materi adalah tim pengabdi sendiri disesuaikan dengan bidang keahlian masing-masing. Materi yang tersajikan 
sebanyak 3bahasan yang masing-masing disajikan oleh anggota Tim Pengabdi sesuai bidang yang bersangkutan. Berikut tabel daftar materi dan pematerinya yang telah terlaksana dalam program PPM ini

\begin{tabular}{|c|c|c|}
\hline $\begin{array}{l}\text { Jenis } \\
\text { Kegiatan }\end{array}$ & $\begin{array}{l}\text { Pokok } \\
\text { Bahasan }\end{array}$ & Pemateri \\
\hline & $\begin{array}{l}\text { Pelatihan } \\
\text { Mangemen } \\
\text { Olahraga }\end{array}$ & Soemardiawan, M.Pd \\
\hline & $\begin{array}{l}\text { Bimbingan } \\
\text { Teknis Prestasi }\end{array}$ & $\begin{array}{l}\text { Intan Primayanti, S.Pd., } \\
\text { M.Or }\end{array}$ \\
\hline & $\begin{array}{l}\text { Prestasi NTB } \\
\text { Menuju } \\
\text { Prestasi Dunia }\end{array}$ & Soemardiawan, M.Pd \\
\hline $\begin{array}{l}\text { Rodmap } \\
\text { Prestasi } \\
\text { Olahraga } \\
\text { NTB }\end{array}$ & & $\begin{array}{l}\text { Soemardiawan, M.Pd, } \\
\text { dan Intan Primayant, } \\
\text { S.Pd., M.Or }\end{array}$ \\
\hline
\end{tabular}

Pelaksanaan program ini melibatkan mahasiswa untuk membantu proses pembimbingan dan praktik agar kegiatan dapat berjalan lancar. Kegiatan tanya jawab dilakukan bersamaan dengan penyajian materi. Para peserta dapat langsung berdiskusi dengan para pemateri secara langsung untuk memahamkan materi dan sharing pengalaman terkait dengan masalah yang tengah dibahas dalam materi bersangkutan.

\section{2) Penugasan Praktik}

Pada akhir materi peserta diberi tugas praktik sesuai materi yang telah disajikan untuk menggali penyerapan dan pemahaman materi serta melihat kreativitasnya dalam membentuk magement olahraga yang berkualiats dengan Hasil pengabdian ini menunjukan terdapat peningkatan yang signifikan kapasitas kemampuan manajemen pengurus provinsi Koni NTT tahun. 2019.

\section{3) Evaluasi dan Penyempurnaan Karya Media Pembelajaran oleh Tim}

Hasil pengabdian ini menunjukan terdapat peningkatan yang signifikan kapasitas kemampuan manajemen pengurus provinsi Koni NTT tahun. 2019. Dalam menjaring data tentang kemampuan manajerial bagi pengurus propinsi cabang olahraga yang ada di NTT dilakukan terlebih dahulu pree test tentang manajemen olahraga, kemudian dilakukan pelatihan menajemen selama 1 hari oleh Koni pusat bekerjasama dengan koni NTT dan fakultas ilmu keolahragaan UNDIKM Mataram. Dan selanjutnya dilakukan post test dengan materi yang sama. Berdasarkan data pree test bahwa rata-rata kemampuan manjerial pengurus propinsi cabang olahraga di NTT sebesar $=78$ (sedang) sedangkan setelah dilakukan pelatihan tentang manajemen olahraga diperoleh data post test sebesar $=84$ (baik), sehingga terdapat peningkatan sebesar $=7,5$.

\section{4) Refleksi dan Penutupan Program Pengabdian Masyarakat}

Di akhir kegiatan peserta dan Tim melakukan refleksi hasil pelatihan dan para peserta juga memberikan evaluasi akan pelatihan ini. Peserta mendapatkan koreksi dan evaluasi Temuan yang menarik dalam penelitian ini adalah(1) bahwa pengurus propinsi cabang olahraga mempunyai latar belakang yang berbeda beda akan tetapi memiliki komitmen yang tinggi dalam memajukan prestasi olahraga di NTT, (3) karena banyak pengurus cabang olahraga yang tidak mempunyai latar belakang organisasi olahraga mereka sangat antusias dalam mengikuti seminar, pelatihan tersebut, (3) masih banyak para pengurus cabang olahraga yang merangkap jabatan dengan organisasi lainya sehingga kurang focus dalam menjalankan organisasi olahraga yang dipimpinya (4) Pendanaan operasional pengurus cabang olahraga berasal dari patungan pengurus dan ketuanya.

\section{HASIL DAN PEMBAHASAN}

Dalam menjaring data tentang kemampuan manajerial bagi pengurus propinsi cabang olahraga yang ada di Sumatera Utara dilakukan terlebih dahulu pree test tentang manajemen olahraga, kemudian dilakukan pelatihan menajemen selama 3 hari oleh Koni pusat bekerjasama dengan koni NTT dan fakultas ilmu keolahragaan UNDIKMA. Dan selanjutnya dilakukan post test dengan materi yang sama.

Berdasarkan data pree test bahwa ratarata kemampuan manjerial pengurus propinsi cabang olahraga di Nusa Tenggara Barat sebesar $=78$ (sedang) sedangkan setelah dilakukan pelatihan tentang manajemen olahraga diperoleh data post test sebesar $=84$ (baik),sehingga terdapat peningkatan sebesar $=7,5$.

Dengan demikian dapat dinyatakan bahwa melalui kegiatan seminar, pelatihan dan workshop kapasitas manajemen olahraga menjadi meningkat, point penting yang dapat diskusikan daman mencermati hasil penelitian tersebut adalah (1) skor yang memperoleh 
nilai yang tinggi dari 9 meteri adalah: (a) Manajemen penyelenggaraan event olahraga, (b) Manajemen pengiriman kontingen ke event olahraga, (c) Menejemen kepemimpinan dalam organisasi olahraga (d), presentasi kelompok yaitu. manajemen event dan manajemen mengiriman atlet. (2) Sedangkan yang memeperoleh skor ratarata adalah materi (a) olimpism sebagai filosofi dasar organisasi olahraga, (b) Manajemen pembinaan olahraga prestasi, (c) Manajemen) indentifikasi bakat olahragawan, (d) Menejemen keuangan dalam organisasi olahraga dan (3) Sedangkan materi (a) Pengetahuan tentang anti doping sangat rendah,Temuan yang menarik dalam penelitian ini adalah(1) bahwa pengurus propinsi cabang olahraga mempunyai latar belakang yang berbeda beda akan tetapi memiliki komitmen yang tinggi dalam memajukan prestasi olahraga diNTT, (3) karena banyak pengurus cabang olahraga yang tidak mempunyai latar belakang organisasi olahraga mereka sangat antusias dalam mengikuti seminar, pelatihan tersebut, (3) masih banyak para pengurus cabang olahraga yang merangkap jabatan dengan organisasi lainya sehingga kurang focus dalam menjalankan organisasi olahraga yang dipimpinya..(4) Pendanaan operasional pengurus cabang olahraga berasal dari patungan pengurus dan ketuanya.

\section{KESIMPULAN}

Terdapat Hasil pengabdian ini menunjukan terdapat peningkatan yang signifikan kapasitas kemampuan manajemen pengurus provinsi Koni NTT tahun. 2019

\section{SARAN}

Disarankan pemimpin sebuah organisasi olahraga memilik kemampuan memimpin organisasi olahraga ditentukan oleh kemampuan manajerial yang dimilki antara lain; kemampuan memimpin, kemampuan membina, kemampuan menyelenggarakan, dan kemampuan menejemen keuangan.

\section{DAFTAR PUSTAKA}

Mochamad Syahroni Firdiansyah (2015) Manajemen Pengelolaan Wahana Rekreasi Olahraga di Wisata Water

Blaster Semarang tahun 2013, Journalof Physical Education, Sport, Health and Recreation, Vol. 4, nomor. 2,Februari.

Ibrahim, M. Izzat. (2015) Manajemen Pengeloaan Penyedia Jasa Pelatih Cabang Olahraga di Kota Semarang Tahun2013.,Journal of Physical Education, Sport, Health and Recreation, Vol. 4, Nomor. 2,Februari Apriyanto,

Agus Abdillah. (2013) Survey Manajemen Wahana Outbound di Pacasan Dream Land Park Kabupaten Bayu Mas Tahun 13. Journal of Physical Education, Sport, Health and Recreation, Vol. 2, Nomor. 10, Oktober

Agung Nugroho, (2010),Manajemen Organisasi Olahraga Prestasi di Propinsi Daerah Istimewa Yogyakarta.http://eprints.uny.ac.id/239/ diakses tanggal 29 Mei 2017

Rizaldi (2015) Studi tentang Manajemen Komite Olahraga Nasional Indonesia Kabupaten Pasaman Barat, Jurnal Ilmu Keolahragaan, Vol. 1 Nomor 1 Setio Nugroho (2016) Manajemen organisasi

Persatuan Renang Seluruh Indonesia (PRSI) Kabupaten Cilacap, Jurnal Unsika, Vol. 4, Nomor 2, Hasan, 1. 2002. PokokPokok Materi Metodologi Penelitian dan Aplikasinya. Jakarta: Ghalia Indonesia

Koni Sumut, (2017), Cabang olahraga dan Koni Kabupaten/Kota Sumatera Utara tahun 2017. Medan :Koni Sumatera Utara Nurul Hidayah, (2016) Manajemen Organisasi Unit Kegiatan Mahasiswa (UKM) Hokey Universitas Negeri Yogyakarta. http://eprints.uny.ac.id/239/ diakses tanggal 29 Mei 2017 Utomo,

Budi.(2015) Manajemen Pengelolaan Lapangan Futsal Se-Kabupaten Boyolali tahun 2013.Journal of Physical Education, Sport, Health and Recreation, Vol. 4, Nomor. 2, Februari

Graham Cuskelly. Tracy Taylor. Russell Hoye. Simon Darcy. (2006) Volunteer Management Practices and Volunteer 
Retention: A Human Resource

Management Approach, Vol. 9, Issue 2

Lorena Hoeber, Orland Hoeber (2012)

Determinants of an Innovation Process:

A Case Study of Technological Innovation in a Community Sport Organization, Journal of Sport Management, Vol 26, issue 3, May

Koni Pusat (2017) Pedoman Pelatihan peningkatan kapasitas manajemen olahraga dan peningkatan kapasitas pelatih fisik koni Kabupaten Kota se Indoensia. Jakarta: Koni Pusat. 